\title{
Modernization of the cooling system in tractors with gas engines
}

\author{
$N A$ Bolshakov $^{1, *}, O N$ Didmanidze $^{1}$, and $E P$ Parlyuk $^{1}$ \\ ${ }^{1}$ Russian State Agrarian University - MAA named after K.A. Timiryazev, Timiryazevskaya st., 49, \\ 127550, Moscow, Russian Federation
}

\begin{abstract}
With an increase in the power/weight ratio of vehicles in cities and towns, the thermal loads of many functional units increase significantly. This requires the organization of the removal of excess heat into the environment, since the violation of the proper thermal regime in individual functional units prevents the realization of the potential operational properties of the entire vehicle up to failure. At the same time, the variety of operating conditions for vehicles, causing a change in a wide range of factors of the working environment, especially road and climatic ones, creates a difficult, both in practical and theoretical terms, problem of ensuring the required thermal regime for functional units. In this regard, the paper presents a consistent development of the theory of hydrothermodynamic properties of functional units based on the principles of constructing the operational properties of vehicles. The problems determining the further search and scientific substantiation of meters and indicators for assessing the efficiency of cooling systems, as well as the development of methods, tools and equipment for calculating and studying these systems are considered. At the same time, the work presents the improvement of the working process and designs of gas engines of tractors aimed at increasing reliability through the use of new production technologies. In conclusion, the definition of scientifically grounded methods and practical solutions for improving the performance of cooling systems is given, which has an important scientific and economic significance for increasing the operational properties of agricultural tractors, substantiating the current importance.
\end{abstract}

\section{Introduction}

In the context of the global crisis, despite some positive trends in the country's economy, the technical equipment of the agricultural industry remains at a low level. Rising prices for service, spare parts, fuels and lubricants, and even with their poor quality in rural areas, significantly increase the cost of the final product.

Meanwhile, the role of the need for automotive vehicles in agricultural production is constantly increasing. It is of great importance in the competition for the markets for agricultural products. The fulfillment of agrotechnical requirements and product quality

\footnotetext{
* Corresponding author: nik.mask@ mail.ru
} 
largely depend on it. The costs of fuel and lubricants make up a significant share in the cost of production, and given the high demand, they are comparable to the costs of its production. Therefore, the issues of using alternative fuels in agriculture are gaining great importance.

Nowadays, the trend of transferring automotive engines to natural gas and improving the designs of agricultural tractors in order to get economic benefits and increase the competitiveness of agricultural producers is of particular importance.

\section{Materials and methods}

\subsection{Theoretical substantiation of the use of the MTZ-80 radiator with a polyurethane core}

\subsubsection{Use of the MTZ-80 radiator with a polyurethane core. Setting goals and objectives}

With an increase in the power/weight ration of cars and tractors, the thermal loads of many functional units (FU) significantly increase. This requires the organization of the removal of excess heat into the environment, since a violation of the proper thermal regime in a separate FU prevents the realization of the potential operational properties of the entire vehicle up to failure $[1-2,6]$. At the same time, the variety of operating conditions for cars and tractors, causing changes in a wide range of factors of the working environment, especially road and climatic ones, creates a difficult, both in practical and theoretical terms, problem of ensuring the required thermal regime of the FU.

In this regard, it is necessary to consistently develop the theory of temperature and dynamic properties (TDP) of FU based on the principles of constructing the operational properties of tractors and cars. Consideration of this problem determines: further search and scientific substantiation of meters and indicators for assessing the effectiveness of cooling systems; development of methods, tools and equipment for the calculation and study of these systems; improving the working process and designs of heat exchange devices, reducing their metal consumption and weight through the use of new environmentally friendly waste-free production technologies [3-4, 7].

The aim of the study is to improve the performance of the MTZ-80 prototype tractor with a polyurethane radiator core and to introduce gas equipment.

The task is to test the modernized agricultural tractor in the field and, using the necessary setups, devices, and measuring and control instruments, to:

- substantiate of the use of a radiator with a polyurethane core in the cooling system of gas engine fuel;

- obtain a technical and economic assessment of the modernized tractor;

- obtain an assessment of the reliability of a radiator with a polyurethane core.

Based on the results of the tests carried out, it is necessary to give a comprehensive assessment of the introduction of design changes to the agricultural tractor.

\subsubsection{Analytical rationale for the use of a radiator with a polyurethane core}

An analysis of existing manufacturers of automotive radiators has shown that there are a fairly large number of companies on the market that offer heat exchangers that differ in their design and performance characteristics. The main manufacturers of radiators that have conquered the Russian market are [5]: 
1. Hella. European brand that merged with the BEHR concern. Supplier for Volkswagen, Audi, Mercedes. Manufactured in China.

2. Termal (Nissens). Taiwan. Premium radiators are attractive due to the price/quality ratio.

3. Denso. Japan. Supplier for Toyota, Subaru, Honda. Manufactured in China.

4. Sakura. Japanese brand for Japanese cars. Manufactured in Indonesia.

5. Blue Print. Korea. Supplier for Korean cars.

6. Parts Mall (PMC) Korean analogue for Korean cars.

7. SAT. China.

8. AVA. European brand. Manufactured in China.

Foreign analogues may not always meet the requirements of the performance characteristics of the heat transfer of domestic internal combustion engines (ICE), including when they are used on gas engines (GE). The latter is caused by the fact that the heat balance changes due to the improvement of individual GE systems.

Along with foreign manufacturers, domestic manufacturers of automotive radiators, which are able to compete not only in Russia, but also abroad, play an important role in the modern market relation. Among the domestic manufacturers of automotive radiators, the following companies can be outlined [5]:

1. LUZAR LLC - St. Petersburg. Manufacturer of automotive radiators of high quality and affordable price. The company supplies products for the assembly shops of AvtoVAZ GM-AvtoVAZ, GAZ, Volkswagen Audi Group, KAMAZ, Ural, etc.

2. Orenburg Radiator LLC - Orenburg. One of the main manufacturers of radiators in Russia and the CIS countries.

3. LLC Dimitrovgrad Automotive Aggregate Plant (LLC DAAZ), Dimitrovgrad. Manufacturer of components, including radiators for auto concerns VAZ, IZH, AZLK, GAZ, UAZ, ZIL, PAZ, LIAZ, URAL, KamAZ, MAZ, etc.

4. PEKAR JSC - St. Petersburg. PEKAR products are manufactured in Russia, meeting the needs of the automotive and spare parts markets for domestic vehicles produced by VAZ, IZH, AZLK, GAZ, UAZ, URAL, KamAZ and MAZ.

5. POAR LLC - St. Petersburg. PO “Auto-Radiator" manufactures automobile products for AVTOVAZ PJSC (Togliatti) and GM-AVTOVAZ CJSC.

6. PRAMOTRONIK LLC - Moscow. The company manufactures products for UralAZ, KamAZ, GAZ vehicles and NefAZ buses.

7. Shadrinsky Automotive Aggregate Plant JSC - Shadrinsk. The products manufactured at the enterprise are supplied to conveyors of automobile factories such as KAMAZ PJSC, MAZ OJSC, MZKT OJSC, NEFAZ OJSC, PJSC Arzamassky machine-building plant, LLC Iveko-AMT, OJSC Mytishchi machine-building plant, OJSC Tuimazinsky plant of autoconcrete trucks, JSC Petersburg Tractor Plant, OJSC Combine of automobile vans, OJSC Shumerlinsky plant of specialized vehicles, PJSC Motovilikha plants, OJSC Kovrovsky electromechanical plant, Generac Power Systems Inc; Sollers Group of Companies: UAZ LLC; GAZ Group of Companies: AZ URAL JSC, AZ GAZ LLC, PAZ LLC, LiAZ LLC, KAVZ LLC; Tractor Plants Concern: OJSC PROMTRACTOR, OJSC Kurganmashzavod; NPK Uralvagonzavod: LLC ChTZ-Engineering Machines, NPK Uralvagonzavod JSC, NPO Elektromashina JSC; RM-Tereks Company: CJSC Bryansk Arsenal, CJSC ChSDM, CJSC Zavolzhsky plant of caterpillar tractors, etc., as well as the market of spare parts.

8. Buguruslansky Plant Radiator JSC - Samara. The company's products are supplied to the largest automotive enterprises in the country: KAMAZ OJSC, Izh-AVTO OJSC, UAZ OJSC, AZ-URAL OJSC. 
9. Termokam LLC - the Republic of Tatarstan, town of Kamskie Polyany. Among the large customers: Chelyabinsk Compressor Plant LLC, Stroydormash JSC (Alapaevsk), Arsenal Mashinostroenie LLC, PO ElAZ JSC.

10. Likhoslavl Radiator Plant OJSC - Likhoslavl. Production of products of this company is supplied to the enterprises of large auto giants of the country UralAZ, KamAZ, GAZ and NefAZ buses.

11. AvtoRad LLC - N. Novgorod. The company mainly produces oil coolers for the internal combustion engine lubrication system and heaters for the interiors of such vehicles as KamAZ, MAZ, Ural, NefAZ, etc.

12. Holding "Composite Group" - Yekaterinburg. Composite Group is the official supplier of heat exchangers for cooling systems for conveyors of leading manufacturers of automotive, agricultural and special equipment: MAZ, BELAZ, URAL, LiAZ, MTZ, Petersburg Tractor Plant - PTZ, Rostselmash, Gomselmash, Bryanskselmash, ChTZUraltrak, Chelyabinsk road-building machines - ChSDM, Machine-building plant named after Kalinin - MziK, Promtraktor - CHETRA, Tver Excavator Plant - TVEKS, Yaroslavl Motor Plant "Avtodiesel”, Production Association "Amkodor" and a number of other large enterprises in Russia and the CIS.

Analysis of existing domestic and foreign manufacturers of heat exchangers showed that basically all manufacturers use the technology for assembling radiator components Nokolok and CuproBraze. The main material of finned plates for all types of automotive radiators is aluminum and copper alloys, although research is underway on alternative structural materials for the cooling core of radiators, such as composite, polymer and powder (porous) [8].
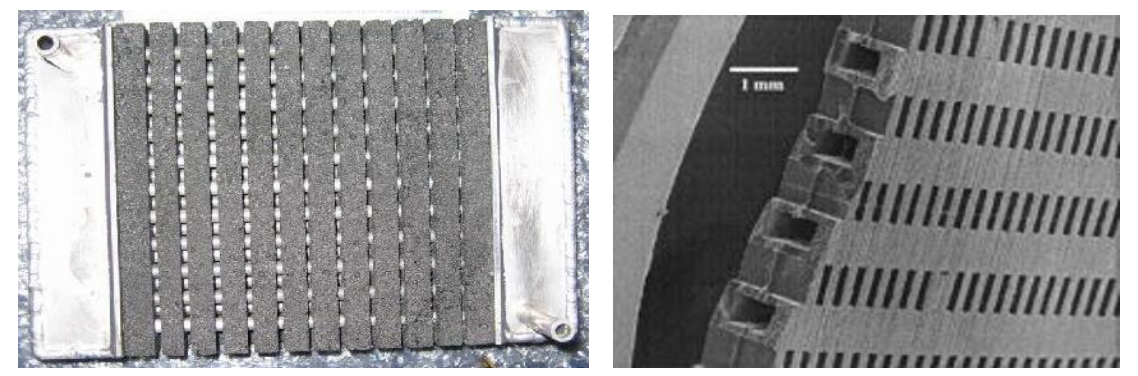

Fig. 1. Alternative automotive radiator made of porous titanium dioxide TiO2 (USA).

In 1987, at the Leningrad Agricultural Institute in the branch research laboratory of aluminum radiators (ONILTA), Professor V.V. Burkov developed and tested a technology for the manufacture of plates with multi-core capillaries in a row; polyurethane was used as the main structural material of the plates [9]. 


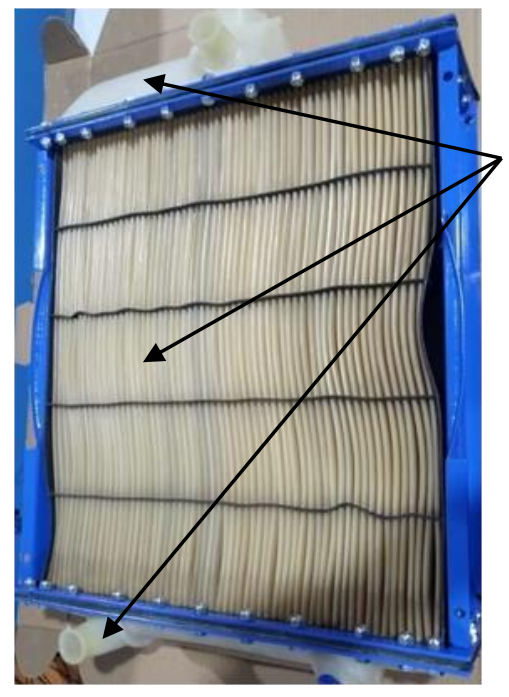

Material of the main radiator elements:

POLYURETHANE

Fig. 2. MTZ-80 tractor radiator of the engine cooling system with a polyurethane core.

In 2007, on the basis of polyurethane plates at the FSBEI HE SPbSAU in the branch research laboratory of aluminum radiators named after V.V. Burkov, the first Russian prototype of a polymer tractor radiator for the internal combustion engine cooling system was manufactured, which is shown in Figure 2.

In 2019, the Scientific and Production Association TALIS LLC together with FSBEI HE SPbSAU, FSBEI HE Timiryazev Agricultural Academy and LUZAR LLC carried out a number of tests of three MTZ-80 radiators, including a prototype of the radiator "ONILTA named after V.V. Burkov" based on a polyurethane core.

Studies of the proposed radiator have revealed a number of advantages:

- low cost;

- low weight;

- impact strength;

- resistance to aggressive environments;

- maintainability;

- service life.

However, there are a number of disadvantages:

- low heat transfer (7-10\% lower in comparison with analog radiators);

- relatively high hydrodynamic resistance (15-17\% higher in comparison with analog radiators).

\subsection{Testing a prototype of the MTZ-80 radiator for engine cooling system based on a polyurethane core}

2.2.1 Testing a prototype of the MTZ-80 radiator for engine cooling system based on a polyurethane core produced by the Branch Research Laboratory of Heat Exchangers named after V. V. Burkov

The purpose of the tests is to determine the functional parameters of the radiator No. 28/319 in accordance with clause 3.1.1 and clause 3.2.4 of the Russian State Standard GOST R 
53832-2010 “Automobile vehicles. Heat exchangers and thermostats. Technical requirements and test methods".

Table 1. Characteristics of the test object.

\begin{tabular}{|c|c|}
\hline Radiator model No.28/3-19 & $\begin{array}{c}\text { MTZ-80 radiator based on polyurethane } \\
\text { core }\end{array}$ \\
\hline Manufacturing plant & $\begin{array}{c}\text { ONILTA named after V.V. Burkov in the } \\
\text { FSBEI HE SPbSAU }\end{array}$ \\
\hline Radiator application & Cooling system \\
\hline Contact type between tube and plate & One-way \\
\hline Number of fluid strokes & 430 \\
\hline Radiator core length, mm & 545 \\
\hline Radiator core width, $\mathrm{mm}$ & 87 \\
\hline Radiator core depth, mm & In-line \\
\hline Arrangement of tubes & Flat oval \\
\hline Tube section & $58 \times 19$ \\
\hline Number of tubes, $\mathrm{pcs}$. & - \\
\hline Tube diameter, $\mathrm{mm}$ & - \\
\hline Number of plates, $\mathrm{pcs}$ & - \\
\hline Plate thickness, $\mathrm{mm}$ & - \\
\hline Spacing of plates, $\mathrm{mm}$ & - \\
\hline Turbulizer & - \\
\hline Radiator weight, $\mathrm{kg}$ & \\
\hline
\end{tabular}

Radiator No. 28/3-19 was tested in the premises of the testing laboratory of Scientific and Production Association TALIS LLC. The radiator tests were carried out in the following scope and in the order provided for in clause 3.2.4, clause 5.1.2 of the Russian State Standard GOST R 53832-2010:

- determination of the reduced heat transfer of the radiator, which was reduced to the difference in the initial temperatures of the heat carriers equal to $60^{\circ} \mathrm{C}$;

- aerodynamic resistance of the radiator (pressure loss of the cold coolant);

- hydraulic resistance of the radiator (pressure loss of the hot coolant).

The tests were carried out using the Thermal air-hydraulic pipe setup designed for heat engineering tests of automobile radiators in accordance with the Russian State Standard GOST R 53832-2010.

\subsubsection{Test results}

Ambient air temperature at the entrance to the test object was $(24.58-27.65)^{\circ} \mathrm{C}$; the corresponding values of the temperature of the heated water were $(80.7-81.32)^{\circ} \mathrm{C}$.

The reduced heat transfer of the radiator No. 28/3-19 to the nominal temperatures of water $80^{\circ} \mathrm{C}$ and air $20^{\circ} \mathrm{C}$ at the air flow rates indicated below and water flow rate of $(5.505$ $\pm 0.005) \mathrm{m}^{3} / \mathrm{h}$ was:

\begin{tabular}{|c|c|}
\hline Air consumption, $\mathrm{kg} / \mathrm{h}$ & Reduced heat transfer, $\mathrm{W}$ \\
\hline 2000.79 & 11168.04 \\
\hline 2988.72 & 16051.83 \\
\hline 4024.71 & 21201.95 \\
\hline 4988.63 & 27429.83 \\
\hline
\end{tabular}


The aerodynamic resistance of the radiator No. 28/3-19 at the indicated air flow rates was:

\begin{tabular}{|c|c|}
\hline Air consumption, $\mathrm{kg} / \mathrm{h}$ & Aerodynamic resistance, $\mathrm{Pa}$ \\
\hline 2000.79 & 16.28 \\
\hline 2988.72 & 35.89 \\
\hline 4024.71 & 67.89 \\
\hline 4988.63 & 120.42 \\
\hline
\end{tabular}

The hydraulic resistance at the water flow rate $(5.505 \pm 0.005) \mathrm{m}^{3} / \mathrm{h}$ for the radiator No. 28/3-19 varied in the range of (38956.03 - 38981.67) Pa.

\subsubsection{Opinions and interpretations regarding recommendations for the use of test results}

For the convenience of using the test results, it is recommended that the reduced heat transfer be reduced to 1 degree Kelvin [10], calculated by the formula:

$$
Q_{\text {red }}=\frac{Q}{t_{1}-t_{2}}
$$

where $\mathrm{Q}$ - reduced heat transfer of the radiator, $\mathrm{W}$;

$t_{1}$ and $t_{2}-$ the temperature of water and air at the inlet to the radiator, respectively, $\mathrm{K}$.

The heat transfer reduced to 1 degree Kelvin of the radiator No. 28/3-19 at the air flow rates indicated below and the water flow rate $(5.505 \pm 0.005) \mathrm{m}^{3} / \mathrm{h}$ was:

\begin{tabular}{|c|c|}
\hline Air consumption, $\mathrm{kg} / \mathrm{h}$ & Heat transfer reduced to $1 \mathrm{~K}, \mathrm{~W} / \mathrm{K}$ \\
\hline 2000.79 & 186.38 \\
\hline 2988.72 & 267.87 \\
\hline 4024.71 & 353.86 \\
\hline 4988.63 & 457.85 \\
\hline
\end{tabular}

\subsection{Operational and technological tests}

\subsubsection{Purpose and brief technical description of the tractor and gas equipment}

The MTZ-82.1 tractor of traction class 1.4 is a wheeled, universal row-crop tractor and is designed for pre-sowing soil cultivation (plowing, harrowing, cultivation), sowing, planting, caring of crops, and harvesting of grain and industrial crops, as well as vegetables and root crops, harvesting herbs, garden and farm work, and transport work.

Gas equipment is installed on the MTZ-82.1 serial tractor, and in this regard, the tractor engine can operate on two types of fuel:

- diesel;

- gas-diesel (mixed fuel) containing:

a) $20-30 \%$ - diesel fuel;

b) $70-80 \%$ - methane gas.

The gas cylinder equipment of the tractor includes: gas cylinders (4 pcs.) with fittings mounted on the tractor cab, filling device, filter, solenoid valve, high pressure reducer, low pressure reducer, gas dispenser, mixer, mechanism for setting the ignition dose of diesel 
fuel, electronic microprocessor control unit, pedal position sensor, as well as tubes, hoses, pressure gauge, fuel type switch.

Working pressure in gas cylinders at full filling reaches $20 \mathrm{MPa}$.

When the engine is running on gas-diesel fuel, the fuel pump rail provides only an ignition dose of diesel fuel in the combustion chamber, which is necessary to ensure ignition of the mixture. The rod travel is limited by the ignition dose mechanism.

Gas is supplied to the cylinders through the engine intake manifold. The supply process takes place in the following order: from the cylinders, compressed gas is supplied through the high pressure pipeline to the solenoid valve, having previously been cleaned from solid impurities in the filter, after opening the solenoid valve, the gas is supplied to the high pressure reducer (HPR), where the gas pressure decreases to $0.8-1.2 \mathrm{MPa}$ (8.0-12.0 $\mathrm{kg} / \mathrm{cm}^{2}$ ), when the pressure is reduced in the HPR, the gas temperature drops, therefore, for heating, the liquid is supplied to the HPR from the engine cooling system with rubber hoses; then the gas enters a two-stage low pressure reducer (LPR), where the gas pressure is further reduced to a value equal to $20 \mathrm{~mm}$ water column $(0.0002 \mathrm{MPa})$; next, the gas enters the metering unit, then to the mixer, and through the intake manifold - to the engine cylinders.

During the tests, no changes were made to the design of the tractor and the gas equipment installed on it, the shortcomings noted during the tests were not eliminated.

\subsubsection{Test conditions for the MTZ-82.1 gas-cylinder tractor in the unit with the PLN- 3-35 plow}

Table 2. Test conditions.

\begin{tabular}{|c|c|}
\hline Indicator & $\begin{array}{c}\text { according to the data of operational } \\
\text { and technological tests }\end{array}$ \\
\hline Test site & Ostrovsky OJSC \\
\hline Working conditions: & sod-podzolic \\
\hline Soil types and name by texture & sandy loam \\
\hline Relief & smooth \\
\hline Microrelief & 19.3 \\
\hline Soil moisture, $\%$, in layers, cm: & 20.5 \\
\hline from 0 to 10 incl. & 0.54 \\
\hline over 10 to 20 incl. & 1.18 \\
\hline from 0 to 10 incl. cm: & 1100 \\
\hline over 10 to 20 incl. & \\
\hline & 14.5 \\
\hline Weil hardness, MPa, int of plant and crop residues per $1 \mathrm{~m}^{2}, \mathrm{~g}$ & plowing \\
\hline Height (length) of plant and crop residues, cm & \\
\hline Prior tillage & \\
\hline
\end{tabular}
75.

Test conditions are determined according to the Russian State Standard GOST 20915- 


\subsubsection{Operational and technological indicators}

Table 3. Operational and technological indicators.

\begin{tabular}{|c|c|c|}
\hline $\begin{array}{c}\text { Type of work and composition of the } \\
\text { unit, timing and place of assessment }\end{array}$ & MTZ-82.1 GE+PLN-3-35 & MTZ-82.1+PLN-3-35 \\
\hline Working width of capture, $\mathrm{m}$ & 1.24 & 1.24 \\
\hline Working speed of movement, $\mathrm{km} / \mathrm{h}$ & 8.91 & 8.40 \\
\hline Productivity per hour, ha & 1.10 & 1.04 \\
\hline main time & 0.98 & 0.91 \\
\hline process time & & \\
\hline $\begin{array}{c}\text { The ratio of the performance of the } \\
\text { compared units, } \%\end{array}$ & 105.8 & - \\
\hline main time & 107.7 & - \\
\hline process time & & 11.6 \\
\hline $\begin{array}{c}\text { Fuel consumption per unit of work } \\
\text { performed during process time }\end{array}$ & $6.1(4.3)$ & 11.6 \\
\hline methane, nm /ha (kg/ha) & 4.63 & 100 \\
\hline diesel fuel, kg/ha & 8.93 & 1 \\
\hline total consumption, conv. kg/ha & 39.9 & \\
\hline $\begin{array}{c}\text { Diesel fuel consumption ratio of } \\
\text { compared units, } \%\end{array}$ & 1 & \\
\hline Number of personnel, persons & & \\
\hline
\end{tabular}

Indicators are determined according to the Russian State Standards GOST 24055-88, GOST 24057-88.

\section{Results}

An operational and technological assessment of the MTZ-82.1 gas-cylinder tractor was carried out at Ostrovsky OJSC by plowing old arable lands with a PLN-3-35 plow.

During the tests, a gas-diesel mode was established: $30 \%$ - diesel fuel and $70 \%$ compressed gas.

The comparison was made against the same background and the type of work when operating the tractor only on diesel fuel.

The test conditions corresponded to the requirements of agricultural production.

Analyzing the obtained indicators, the following conclusions can be done:

- as a result of an increase in the operating speed of the MTZ-82.1 tractor with a PLN-335 plow during its operation in the gas-diesel mode, an increase in productivity was obtained for 1 hour of the main and process time by $5.8 \%$ and $7.7 \%$, respectively;

- diesel fuel consumption is reduced by $60.1 \%$;

- indicators of the quality of the technological process correspond to agricultural requirements.

\section{Conclusions}

In this work, studies were carried out to improve the performance of a prototype MTZ-80 tractor with a polyurethane core radiator and the introduction of gas equipment.

As a result of the studies carried out on a prototype of a radiator in comparison with analog samples of well-known manufacturers, the following conclusions can be drawn:

1. The prototype of the MTZ- 80 radiator with a polyurethane core has great prospects as an alternative radiator of the future; 
2. Increasing the heat transfer of the radiator by $10-15 \%$ is possible using an integrated approach of using aluminum fins on the surface of the polyurethane plate;

3. A decrease in the hydrodynamic resistance by $15-20 \%$ is possible due to an increase in the diameter of the throughput of the capillaries in the polyurethane plate and the number of the plates themselves in the radiator honeycomb.

4. Tests of the modernized agricultural tractor were carried out in the field and using the necessary setups, devices, and measuring and control instruments, as a result of which the following conclusions were obtained:

5. it was found that in the gas-diesel mode of the engine operation, the productivity for 1 hour of the main and process time is higher than the productivity obtained when working on diesel fuel due to the increase in the working speed of the tractor by $5.8 \%$ and $7.7 \%$;

6. diesel fuel consumption is reduced by $60.1 \%$.

The quality of performing technological process on the plowed land meets agricultural requirements.

The research was supported by the Russian State Agrarian University - Moscow Timiryazev

Agricultural Academy, theme №352 1.2.2.

\section{Reference}

1. Afanas`ev A S, Xakimov R T, Pechurin A A 2018 Metodika ispy`taniya kabin avtotransportnoj texniki v laboratorny`x usloviyax Transport Rossii: problemy` $i$ perspektivy`Materialy`mezhdunarodnoj-nauchno-prakticheskoj konferencii pp 99-105

2. Afanas`ev A S, Xakimov R T, Pechurin A A 2017 Temperaturno-dinamicheskie ispy`taniya sistem kondicionirovaniya kabin avtotransportnoj texniki Servis bezopasnosti $v$ Rossii: opy`t, problemy', perspektivy Obespechenie kompleksnoj bezopasnosti zhiznedeyatel 'nosti naseleniya materialy`IX Vserossijskoj nauchnoprakticheskoj konferencii (Saint-Petersburg University of the State Fire Service of the EMERCOM of Russia) pp 266-271

3. Dzyuba E Yu, Xakimov R T 2015 Analiz sredstv ocenki konstrukcii i rabot po alyuminievy`m radiatoram, provodimy`x $\mathrm{v}$ laboratorii "ONILTA" Izvestiya Mezhdunarodnoj akademii agrarnogo obrazovaniya № 25-1 99-101

4. Didmanidze O N, Xakimov R T, Parlyuk E P, Bol`shakov N A 2019 Puti sovershenstvovaniya oxlazhdayushhix sistem pri ispol'zovanii metana $\mathrm{V}$ gazomotorny`x dvigatelyax Doklady`TSXA 7-10

5. Didmanidze O N, Bol`shakov N A, Xakimov R T 2018 Uluchshenie e`kspluatacionny`x pokazatelej avtomobilej putem sovershenstvovaniya oxlazhdayushhix sistem Avtotransportnaya Texnika XXI Veka sbornik statej III Mezhdunarodnoj nauchno-prakticheskoj konferencii ed O N Didmanidze, N E Zimina, D V Vinogradova pp 29-45

6. Eroxin M N, Didmanidze O N, Parlyuk E P, Xakimov R T 2019 Matematicheskaya model processa sgoraniya i teplovy`deleniya v cilindre gazovogo dvigatelya Chteniya akademika V.N. Boltinskogo (115 let so dnya rozhdeniya) ed M N Eroxina 19-28

7. Xakimov R T 2012 Model korrelyacii vy`brosov vredny`x veshhestv avtomobilya s ispol zovaniem dinamometricheskogo testirovaniya Texniko-texnologicheskie problemy`servisa № 2 (20) 15-19

8. Xakimov R T 2010 E`kologicheskoe sostoyanie transporta v Rossii Transport Rossii problemy`i perspektivy`Vserossijskaya nauchno-prakticheskaya konferenciya: Trudy` 
konferencii pp pp 221-222

9. Erokhin M N, Didmanidze O N, Aldoshin N V, Khakimov R T 2019 The combustion process and heat release in the gas engine Proceeding of 7 th International Conference on Trends in Agricultural Engineering (PAE 2019) pp 607-611

10. Khakimov R, Shirokov S, Zykin A, Vetrova E 2017 Strategic assessment aspect of vehicles' technical condition influence upon the ecosystem in regions Transportation Research Procedia 295-300 